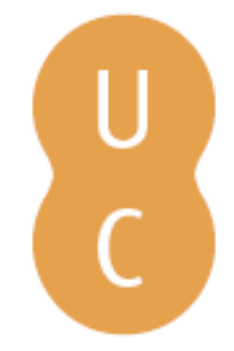

\title{
nommalina
}

\section{Ignition/non ignition phase transition}

\author{
Autor(es): $\quad$ Sahila, A.; Harrouz, O.; Zekri, N.; Kaiss, A.; Clerc, J-P.; Rahli, O.; Giroud, \\ F.; Picard, C.
}

Publicado por: Imprensa da Universidade de Coimbra

URL persistente:

URl:http://hdl.handle.net/10316.2/44572

DOI:

DOI:https://doi.org/10.14195/978-989-26-16-506_55

Accessed : $\quad$ 26-Apr-2023 10:10:00

A navegação consulta e descarregamento dos títulos inseridos nas Bibliotecas Digitais UC Digitalis, UC Pombalina e UC Impactum, pressupõem a aceitação plena e sem reservas dos Termos e Condições de Uso destas Bibliotecas Digitais, disponíveis em https://digitalis.uc.pt/pt-pt/termos.

Conforme exposto nos referidos Termos e Condições de Uso, o descarregamento de títulos de acesso restrito requer uma licença válida de autorização devendo o utilizador aceder ao(s) documento(s) a partir de um endereço de IP da instituição detentora da supramencionada licença.

Ao utilizador é apenas permitido o descarregamento para uso pessoal, pelo que o emprego do(s) título(s) descarregado(s) para outro fim, designadamente comercial, carece de autorização do respetivo autor ou editor da obra.

Na medida em que todas as obras da UC Digitalis se encontram protegidas pelo Código do Direito de Autor e Direitos Conexos e demais legislação aplicável, toda a cópia, parcial ou total, deste documento, nos casos em que é legalmente admitida, deverá conter ou fazer-se acompanhar por este aviso.

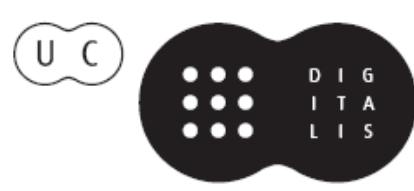




\section{ADVANCES IN}

\section{FOREST FIRE RESEARCH}

\section{8}

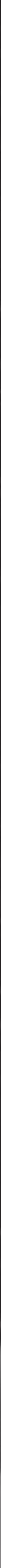




\section{Ignition/non ignition phase transition}

F. Z. Sabi ${ }^{1}$; M. S. Terrah ${ }^{1}$; O. Mosbah ${ }^{1}$; A. Dilem ${ }^{1}$; N. Hamamousse ${ }^{1,2}$; A. Sahila ${ }^{1}$; O. Harrouz ${ }^{1}$; N. Zekri' ${ }^{*}$; A. Kaiss ${ }^{2}$; J-P. Clerc ${ }^{2}$; O. Rahli ${ }^{2}$; F. Giroud ${ }^{3}$; C. Picard ${ }^{3}$

${ }^{1}$ Université des Sciences et de la Technologie d'Oran, LEPM BP 1505 El Mnaouer Oran, Algeria, \{nzekri@yahoo.com*\}

${ }^{2}$ Aix Marseille Université. CNRS, IUSTI UMR 7343, 13453 Marseille, France

${ }^{3}$ CEREN, Domaine de Valabre, 13120 Gardanne, France

\section{Abstract}

The flammable/non flammable transition is investigated both experimentally and numerically within the framework of statistical mechanics and percolation-type phase transitions. The heat flux threshold for ignition is usually estimated deterministically by fire research community. It is defined actually by ASTM standards as the average between the minimum flux allowing ignition and the maximum one which does not allow it. The probabilistic aspect of the ignition transition is demonstrated here, and a new method for the estimation of the ignition critical heat flux is proposed.

Dead wheat straw and live pinus halepensis needles are investigated experimentally using a cone calorimeter and numerically using a simple physical model. The experimental data on ignition time are different from those obtained numerically. This difference is due to the fact that the numerical model assumes auto-ignition whereas experimental data are obtained by using a pilot flame. It is found that the variation of ignition time with the incident heat flux obeys a universal power-law behaviour near the heat flux threshold. The critical heat flux for ignition estimated from this law is also obtained using the ignition probability method. This critical heat flux is as low as it cannot be obtained using the ASTM standards. The power-law exponent is found compatible for both dead straw and pinus halepensis suggesting a universal phase transition.

Further discussions on the comparison between flammability transition and spread/non spread transition are provided.

Keywords: Critical heat flux, flammability, phase transition

\section{Introduction}

The critical condition for ignition is an important property that allows land managers and fire operationals to control its spread. The most common criterion is based on the assumption that ignition occurs when a critical temperature at the surface, $T_{i g n}$, is reached. Piloted ignition occurs when the lower flammability limit is reached in the fuel-air mixture around the pilot flame. An increasing number of works were devoted to the study of the critical heat flux of fuel ignition (see Quintiere and Harkleroad 1984, Dietenberger 1996, Mikkola and Wichman 1989, Delichatsios and Chen 1993, Mindykowski et al. 2011). On the other hand, a still unexplained empirical observation is the "moisture of extinction" (Cohen and Bradshaw, 1986; Rothermel, 1972; Weise et al., 2005). Wildland fires in dead fuels will not spread above some threshold of fuel moisture content, typically assumed to be between 10\% and 40\% (Rothermel, 1972). Terrah et al. (Terrah et al. 2018) have shown no critical moisture content for ignition, and that phase transition is due to the critical heat flux for ignition. In a wildland fire, the heat flux produced by a flame depends on the mass of the flaming fuel. A proportion of this flux is received by the fuel exposed to the flame. The critical received heat flux for ignition corresponds then to a critical mass of the decomposing fuel. As the fuel is heterogeneous, it induces the emission of multiple heat fluxes and various flaming durations. Then, there is an effective heat flux induced by the heterogeneous decomposing fuel. Furthermore, to ensure spreading of wildland fires,

Advances in Forest Fire Research 2018 - Page 506 
the residence time of the burning fuel must be larger than the ignition time of the one which is exposed to the flame. As the flame residence time is always finite (e.g. around 30s for pine needles and straw if arranged in non-compacted beds), two transition thresholds appear: propagation and ignition thresholds. The critical heat flux for the propagation transition is thus larger than that of ignition transition. It is useful to express these transitions in terms of the ignition and combustion energies. Fig. 1 shows a schematic behaviour of the ignition and combustion energies as a function of the incident heat flux for the same fuel sample. As the received heat flux increases, the ignition energy (or ignition time) decreases, but the combustion energy (or residence time) increases (Chandler et al. 1983, Trabaud 1992). For simplicity the trends are shown here linear. The ignition transition occurs when the energy received from a heat flux, even during an infinite time, reaches the fuel ignition energy. Propagation/non propagation transition occurs if the flaming fuel combustion energy reaches the ignition energy of the exposed fuel (see the arrow of Fig.1). In 2005, (Zekri et al. 2005) have distinguished this transition from the percolation transition induced by the fuel inhomogeneity, and called its threshold the dynamical threshold. In the present work, we focus on the ignition transition, where the sample is exposed to a heat flux during a sufficient time for its ignition, as realised with a cone calorimeter.

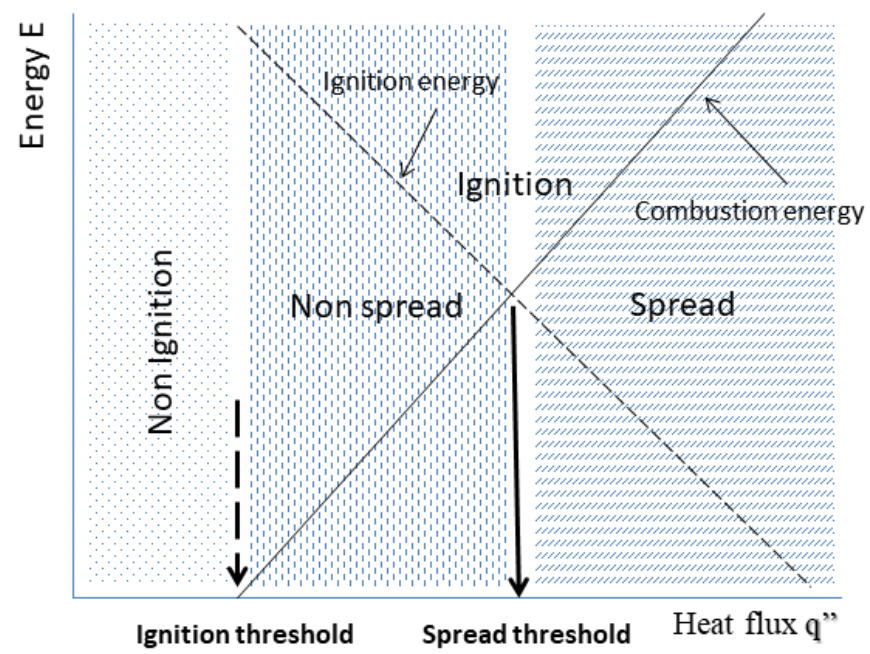

Figure 1 - A schematic representation of the ignition and combustion energies vs. the incident heat flux. Ignition and spreading thresholds are clearly shown.

Most of the studies using a cone calorimeter estimated the ignition critical heat flux from a linear fit of the inverse of ignition time as a function of the incident heat flux (Khan et al. 2008, Mindykowski 2011). However, the linear behaviour of the inverse of ignition time is observed only for high heat fluxes, whereas fluctuations and nonlinearity appear in the limit of low fluxes near the critical one. Therefore, the critical heat flux for ignition could be overestimated by such a fitting. On the other hand, the ASTM 1354 standards define the critical heat flux as the average value between the maximum flux where ignition cannot occur and the minimum one where it occurs. This definition induces an inherent uncertainty in the estimation of the critical heat flux.

Phase transitions, as observed in various fields such as conductor/insulator (Stauffer 1992), liquid/gas (Blundell et al. 2006) and paramagnetic/ferromagnetic (Stanley 1971, Pokrovskii 1999), are characterized by a strong disorder near the threshold. They are also characterized by diverging or vanishing quantities following a universal power-law formula near the critical region (Stanley 1971, Yeomans 1992). In the case of ignition/non ignition (or exothermic/endothermic) phase transition, ignition time must diverge as:

$$
t_{i g n} \sim\left(q^{\prime \prime}{ }_{i n c}-q^{\prime \prime}\right)^{-\gamma}
$$


Where $q{ }^{\prime \prime}{ }_{i n c}$ is the incident heat flux, $q{ }^{\prime}{ }_{c}$ the critical heat flux for ignition and $\gamma$ the critical exponent. This exponent expresses the rate of increase of the ignition time near the critical region. There should be also a probability of ignition near the critical region because of the disorder.

In the present work, the critical heat flux is estimated within the framework of phase transitions. Numerical simulations using a simple model (Koo et al. 2005) and experimental data on pinus halepensis and wheat straw using a cone calorimeter are considered.

\section{Experimental setup}

Two different species of vegetation have been used: wheat straw (dead fuel) at around $12 \%$ moisture content (august 2017) and pinus halepensis needles (live fuel) at 52\% moisture content (January 2018). Samples of Pinus halepensis are picked and burned on the same day to guarantee their properties of live fuel. This ensures that all the burned samples contain the same organic volatile composition.

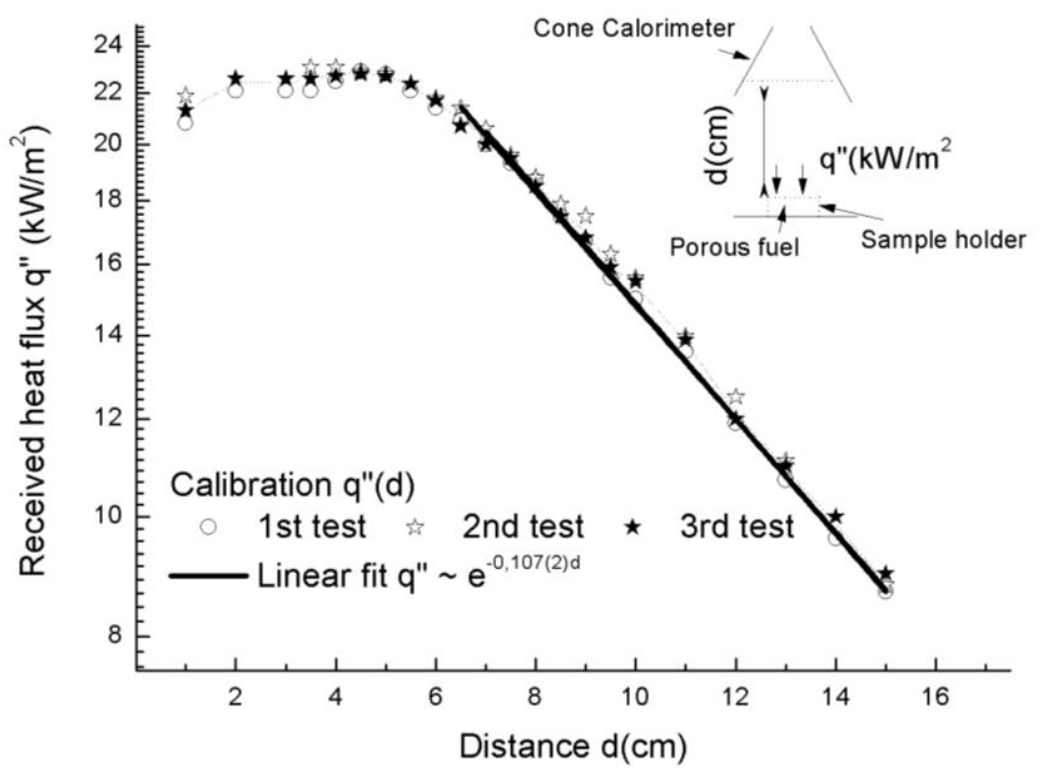

Figure 2 - A schematic representation of the calibration flux and the experimental setup.

Samples of $10 \mathrm{~g}$ mass were placed in a cylindrical holder of $10 \mathrm{~cm}$ diameter of a mesh shape, corresponding to a load of $1.27 \mathrm{~kg} / \mathrm{m}^{2}$. A cone calorimeter with an electrical resistance of a power of $3000 \mathrm{~W}$ as a heat source provides a heat flux to the samples. The samples are placed at different distances from the heat source so as to receive radiation heat fluxes $q^{\prime \prime}=q^{\prime \prime}{ }_{\text {inc }}$ of magnitudes ranging from 9 to $20 \mathrm{~kW} / \mathrm{m}^{2}$. The variation of the received heat flux is realized by changing the distance between the sample top surface and the heat source of the cone calorimeter. The experimental device and the incident heat flux calibration are shown schematically in Fig.2. The incident heat flux at the top surface position of the sample is calibrated by using a water cooled heat flux sensor of type Hukseflux SBG 01 working in the range $0-200 \mathrm{~kW} / \mathrm{m}^{2}$. The ignition is controlled by a pilot flame located $1 \mathrm{~cm}$ above the sample top surface, and the ignition time is recorded. In order to compare the experimental data with the numerical results where ignition process is auto- ignition, a test for wheat straw was realized by removing the pilot flame and closing the cone calorimeter on its top side. This allows us to get closer to auto-ignition, which is difficult to realize in all tests. Because of the heterogeneity of the sample structure, up to five (5) tests are repeated in order to determine the time to ignition as defined by ASTM standards (only one test is realized for wheat straw). The tests were conducted in a draft-free room with room temperatures and relative humidities in the ranges $13-19^{\circ} \mathrm{C}$, and $50-60 \%$, respectively for pine needles and $20-30^{\circ} \mathrm{C}$ and $45-55 \%$ for wheat straw.

Advances in Forest Fire Research 2018 - Page 508 


\section{Model description}

As stated by Drysdale (Drysdale 2011), the flame is a gas phase phenomenon and, clearly, flaming combustion of liquid and solid fuels must involve their conversion to a gaseous form. Oxygen/flammable gas mixture ignits at an ignition temperature when it reaches its flammability limit. It is difficult to find a simple model describing the fuel solid/gas and liquid/gas transitions and gas flammability. The present model assumes autoignition, and uses the criterion of ignition temperature at the surface of the fuel. It is assumed that the sample receives a radiative heat flux $q^{\prime \prime}=q^{\prime \prime}{ }_{i n c}$ from the cone calorimeter. The effective heat flux $q^{\prime \prime}$ eff absorbed by the sample is:

$$
\mathrm{q}^{\prime \prime}{ }_{\text {eff }}=\mathrm{q}^{\prime \prime} \text { inc }-\mathrm{q}^{\prime \prime} \text { lost }
$$

Where $q^{\prime \prime}$ lost is the heat flux lost by the sample. The lost heat flux increases as the sample temperature increases. If we assume that the whole heat lost is radiative, we can express it as:

$$
\mathrm{q}_{\text {lost }}=\sigma \varepsilon_{\mathrm{fb}}\left(\mathrm{T}^{4}-\mathrm{T}_{0}^{4}\right)
$$

Where $\varepsilon_{f b}$ is the sample emissivity, $\sigma$ the stephen-Boltzman constant and $T_{0}$ the ambient temperature. The effective energy received during the ignition time is used to increase the sample temperature up to ignition temperature in three steps: $i$ ) increase of the moist sample temperature up to boiling $\left.\left(373^{\circ} \mathrm{K}\right), i i\right)$ evaporation of the water mass $m_{w}$ from the sample, iii) increase of the dry sample temperature until it reaches the ignition temperature. If we neglect the heat of desorption of water, the energy conservation becomes:

$$
\int_{0}^{\mathrm{t}_{\mathrm{ign}}} \mathrm{q}_{\text {eff }} \mathrm{dt}=\left\{\begin{array}{c}
\int_{\mathrm{T}_{0}}^{373^{\circ} \mathrm{K}}\left(\mathrm{m}_{\mathrm{dry}} \mathrm{c}_{\mathrm{p}}^{\mathrm{fb}}+\mathrm{m}_{\mathrm{w}} \mathrm{c}_{\mathrm{p}}^{\mathrm{w}}\right) \mathrm{dT}+ \\
\int_{\mathrm{m}_{\mathrm{w}}}^{0} \mathrm{~L}_{\mathrm{v}}\left(373^{\circ} \mathrm{K}\right) \mathrm{dM}+ \\
\int_{373^{\circ} \mathrm{K}}^{\mathrm{T}_{\mathrm{ign}}} \mathrm{m}_{\mathrm{dry}} \mathrm{c}_{\mathrm{p}}^{\mathrm{fb}} \mathrm{dT}
\end{array}\right.
$$

Here $c_{p}^{f b}, c_{p}^{w}$ are the specific heat of the dry fuel and water respectively $\left(c_{p}^{f b}=1827 \mathrm{~J} / \mathrm{kg} / \mathrm{K}\right.$ for pinus halepensis needles, $1700 \mathrm{~J} / \mathrm{kg} / \mathrm{K}$ for wheat straw and $4180 \mathrm{~J} / \mathrm{kg} / \mathrm{K}$ for water), $L_{v}=2257 \mathrm{~kJ} / \mathrm{kg}$ the water latent heat at $373^{\circ} \mathrm{K}$, and $m_{d r y}$ and $m_{w}$ are the dry fuel and water masses exposed to the incident flux. The fuel moisture constant is defined as:

$$
h(\%)=\frac{m_{w}}{m_{d r y}+m_{w}} \times 100
$$

In order to be coherent with the experimental setup, the fuel mass can be expressed as:

$$
m_{\text {fuel }}=\phi . \rho_{\text {fuel }} . S . e
$$

Where the fuel density $\rho_{\text {fuel }}$ is around $500 \mathrm{~kg} / \mathrm{m}^{3}$ for the wheat straw and $789 \mathrm{~kg} / \mathrm{m}^{3}$ for pinus halepensis needles, $S$ the surface occupied by the fuel (in $m^{2}$ ) and $e$ the fuel thickness (in $m$ ). The packing ratio $\phi$ is the ratio of solid fuel volume to fuel bed volume. As the effective heat flux in the left side of (4) is usually expressed in $\mathrm{kW} / \mathrm{m}^{2}$, it is useful to introduce the fuel load $\sigma_{\text {fuel }}=m_{f u e l} / S$ (in $\mathrm{kg} / \mathrm{m}^{2}$ ). In order to compare with the experimental results, the fuel load is taken $1.27 \mathrm{~kg} / \mathrm{m}^{2}$ in all simulations.

\section{Results and discussions}

In order to understand the temperature behaviour near the critical region, let us consider the simulation model described in the previous section. When exposed to a heat flux, the fuel surface temperature increases according to (4), but the lost heat flux increases according to (3), and the 
received effective flux is reduced as a consequence. If the heat flux is not sufficient to ignite the fuel, its surface temperature reaches asymptotically a maximum temperature $T_{\max }$ (obviously smaller than $\mathrm{T}_{\mathrm{ign}}$ ), so that the whole incident flux is lost. Thus, the surface temperature becomes nearly constant near $\mathrm{T}_{\max }$ (see Fig.3a). For the experimental tests on wheat straw, where the heat flux is not sufficient, the surface temperature was shown to reach a maximum value, then it decreases and becomes constant. This is due to the change in the specific heat of the sample because of the straw thermal degradation. The maximum temperature $\mathrm{T}_{\max }$ increases as the incident flux increases. Hence, the ignition critical flux corresponds to the condition $\mathrm{T}_{\text {ign }}=\mathrm{T}_{\max }$. In this limit, the fuel reaches the ignition temperature after an infinite time $\left(t_{\text {ign }} \rightarrow \infty\right)$. The ignition time becomes finite above the critical heat flux (Fig.3b).

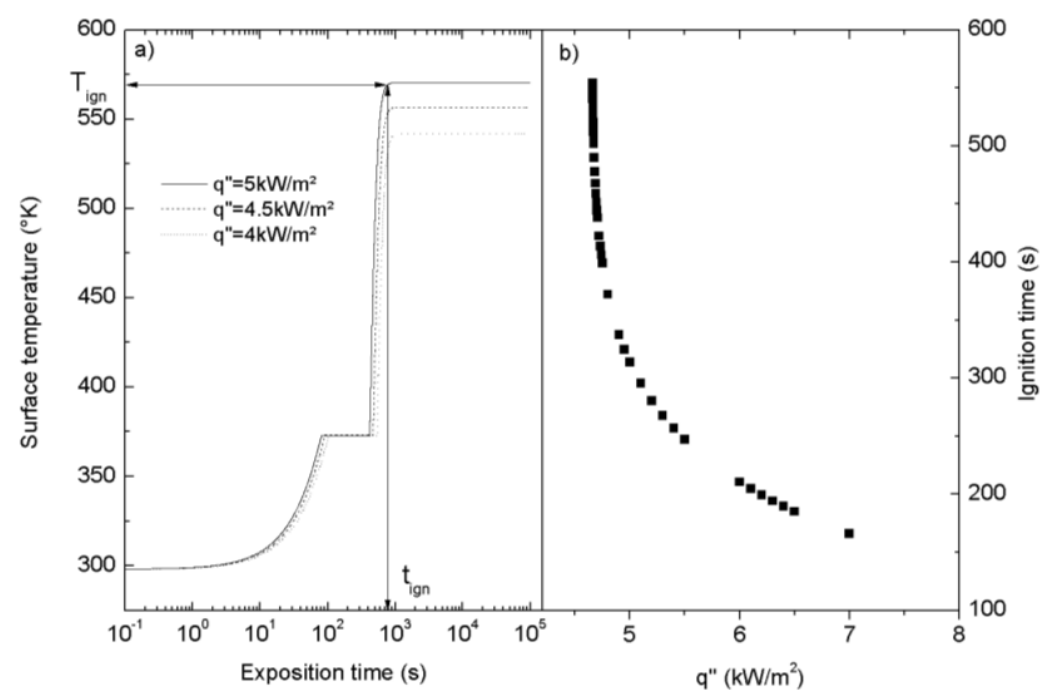

Figure 3 - Simulation for wheat straw of: a) Surface temperature vs. time of exposition for various incident fluxes. b) Ignition time vs. heat flux.

Note in Fig.3b, the strong variation of the ignition time near the critical heat flux (few $\mathrm{W} / \mathrm{m}^{2}$ ). This variation of the heat flux is impossible to realize experimentally. Furthermore, the fluctuations of ignition time are observed experimentally because of the heterogeneity of the sample shape, thickness, porosity etc. The simulation model can be considered as a mean field one. Assuming that the ignition time divergence in Fig.3b obeys the phase transition universal law (1), experimental and numerical data are presented in Fig.4 in a double logarithmic scale as a function of the incident heat flux in reference to the critical flux. A linear behaviour in Fig.4 corresponds to (1). The value of the ignition critical heat flux is estimated so as to obtain the best linear fit.

The ignition critical heat flux is clearly much larger for wheat straw $\left(\mathrm{q}^{\prime \prime} \sim 10 \mathrm{~kW} / \mathrm{m}^{2}\right)$ than for pinus halepensis $\left(\mathrm{q}_{\mathrm{c}} \sim 6 \mathrm{~kW} / \mathrm{m}^{2}\right)$. This confirms the large fire susceptibility index of pinus halepensis in the mediterranean wildlands (Alexandrian and Rigolot 1992). The simulation results of ignition critical heat flux $\left(q^{\prime \prime}{ }_{c} \sim 4.6 \pm 0.5 \mathrm{~kW} / \mathrm{m}^{2}\right)$ and ignition time for wheat straw using auto-ignition are very different from those obtained from experimental data for this fuel with piloted ignition (where the critical heat flux is $q^{\prime \prime}{ }_{c}=10.3 \pm 0.5 \mathrm{~kW} / \mathrm{m}^{2}$ ). This is due to the difference in the ignition process. As described above, the auto-ignition considered for the simulation model is difficult to realize experimentally, since it assumes solid fuel ignition. In fact, as the fuel temperature increases, a solidgas or a solid-liquid-gas phase transition occurs. The flammable gas/air mixture must reach ignition temperature at the fuel surface while it escapes from it. A mechanism to simplify the ignition process is to include a pilot flame or a hot spot. Then, there is no need for the gas/air mixture, when it reaches its lower flammability limit, to wait for the ignition temperature to be reached at the surface, since the pilot flame provides it (Torero 2016). 
In order to be closer from the auto-ignition condition and be able to compare with the simulations results, the pilot flame is removed, and the cone calorimeter closed at its top side. The ignition time is much larger than that of the pilot flame for the same heat flux (see star in Fig.4), but is also larger than the expected ignition time from the simulation model. In addition, the ignition did not occur at the fuel surface (auto-ignition), but inside the closed cone which plays the role of a hot source. The model clearly fails to reproduce experimental data. Obviously, it does not account for the fuel gas emission and flow at the sample surface. This kind of models is often used to describe wildland fire spread (Adou et al. 2010). Hence, these models must be improved to explain some unexpected situations such as junction fires (Viegas et al. 2012).

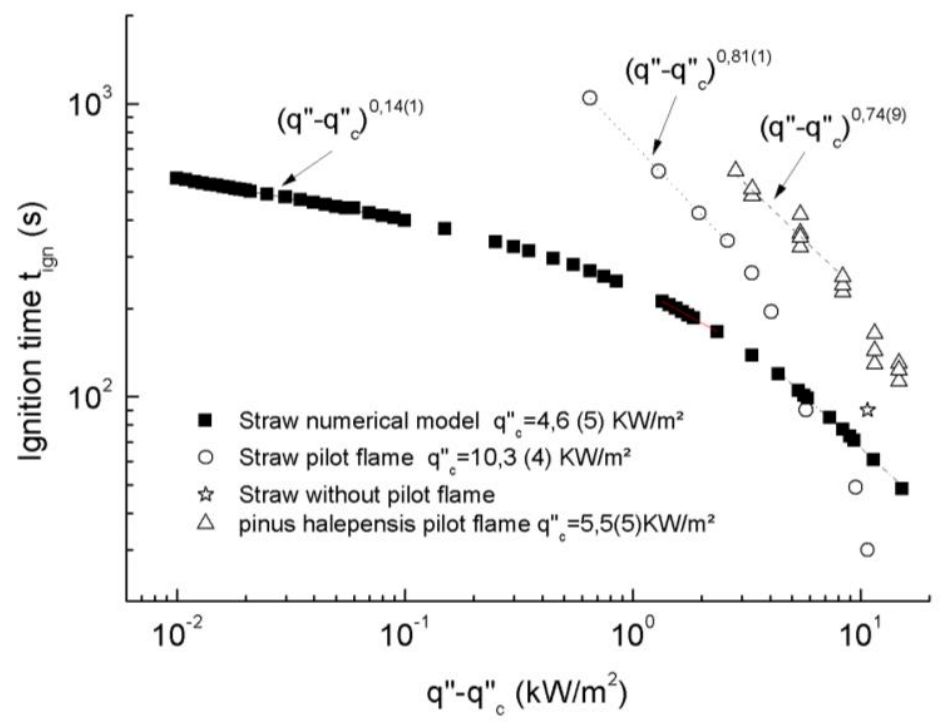

Figure 4 - Ignition time vs. $q^{\prime \prime}-q^{\prime \prime}{ }_{c}$ for the simulation model and experimental data on dead straw and live pinus halepensis. One data without pilot flame is presented for comparison.

In the recent experimental investigation of the ignition critical heat flux (Mindykowski et al. 2011), using a fire propagation aparatus, a linear behaviour of the inverse of ignition time was assumed. This behaviour corresponds to (1) with an exponent $\boldsymbol{\gamma}=\mathbf{1}$. However, the linear behaviour of the inverse of ignition time was observed for incident heat fluxes far from the critical region. In the present results (Fig.4), the exponent is around $\boldsymbol{\gamma}=\mathbf{0 . 1 4}$ for numerical simulation and $\boldsymbol{\gamma} \sim \mathbf{0 . 7 5}$ for experimental results both for dead wheat straw and live pinus halepensis. Therefore, near the critical region the inverse of ignition time behaves nonlinearly in contrast to the assumption of Mindykowski et al. As for the ignition critical heat flux and ignition time, the difference between the values of exponents for numerical and experimental results can be attributed to the ignition process difference (auto-ignition and pilot flame). The equality of the exponents for wheat straw and pinus halepensis suggests a universal ignition phase transition (Stanley 1971, Yeomans 1992).

The results of Fig.4 revealed an increasing number of tests that failed to ignite as the critical region is approached. This means that a percolation-type probabilistic behaviour occurs near the critical region (Stauffer 1992). In ASTM standards, only five (05) tests are repeated for each heat flux, which means that the minimum estimated ignition probability is $20 \%$. If for a given heat flux, all the five tests fail to ignite, it is decided that the flux threshold is not reached according to ASTM standards. Nevertheless, for the critical heat flux estimated from (1), the ignition probability might be much smaller than $20 \%$. Therefore, the ignition critical heat flux is overestimated when ASTM standards are used. As a consequence, such standards must be re-examined for fire safety.

Fire management at the wildland-urban interface requires fuel-breaks of width depending on front fire intensity. In order to stop the propagation of wildland fire to the urban zone, the heat flux at this region must be smaller than the critical spread flux. Therefore, an overestimation of this critical flux 
(underestimation of the width of fuel-break) leads to a fire spread in the urban zone. The determination of the ignition critical heat flux from Figs 1 and 3 allows us to have a better estimation of the heat flux threshold for fire spread. This will help us to preserve the urban habitat from fire propagation.

\section{Conclusion}

The ignition phase transition was investigated both experimentally using a cone calorimeter and numerically using a simple physical model. Wheat straw and pinus halepensis fuel samples were used for this end. Unlike ASTM standards for which ignition threshold is estimated deterministically, the probabilistic aspect of the ignition transition was pointed out, and a new method for the estimation of the ignition critical heat flux was proposed using the framework of statistical mechanics and percolation-type phase transitions.

The variation of ignition time with the received heat flux was found to obey a universal power-law behaviour near the ignition heat flux threshold (see Eq.1). The flux threshold estimated from this law is lower than the ASTM standards estimation.

A further study of the universality of the ignition transition and its connection to the spread/non spread transition is necessary.

\section{References}

Adou JK, Billaud Y, Brou DA, Clerc JP, Consalvi JL, Fuentes A, Kaiss A, Nmira F, Porterie B, Zekri L., Zekri N (2010), Simulating wildfire patterns using a small-world network model, Ecol.Modelling, 221, 1463-1471.

Alexandrian D and Rigolot E (1992), Sensibilité du pin d'Alep à l'incendie, Forêt méditerranéenne, 3, 185-198.

Blundell SJ and Blundell KM (2006), 'Concepts in Thermal Physics', (Oxford University Press, Oxford).

Chandler C, Cheney P, Thomas P, Trabaud L, Williams D (1983) 'Fire in forestry. Vol. I. Forest fire behaviour and effects.' (John Wiley \& Sons: New York)

Cohen J and Bradshaw B (1986) Fire behavior modeling - A decision tool. In 'Proceedings Prescribed Burning in the Midwest: State of the Art ' (Ed. A. L. Koonce), University of Wisconsin at Stevens Point, Stevens Point, WI, 1-5.

Dietenberger M (1996), Ignitability Analysis using the Cone Calorimeter and LIFT Apparatus, Proceedings of the International Conference on Fire Safety, Columbus,OH, 22, 189-197.

Delichatsios M, Chen Y(1993) Asymptotic, Approximate, and Numerical Solutions for the Heatup and Pyrolysis of Materials Including Reradiation Losses, Combustion and Flame, 92, 292-307.

Khan MM, De Ris JL, Ogden SD (2008) Effect of Moisture on Ignition Time of Cellulosic Materials, Fire Safety Science-proceedings of the Ninth International Symposium, 167- 178.

Koo E, Pagni P, Woycheese P, Stephens S, Weise D, Huff J (2005) A Simple Physical Model for Forest Fire Spread Rate, Fire Safety Science-proceedings of the Eighth International Symposium, 851-862

Mikkola E, Wichman I (1989), On the Thermal Ignition of Combustible Materials, Fire and Materials, 14, 87-96.

Mindykowski P, Fuentes P, Consalvi JL, Porterie B (2011), Piloted Ignition of Wildland Fuels, Fire Safety Journal 46 (1-2), 34-40.

Pokrovskii VL, (1999), Two-dimensional magnetic phase transitions, J.Magnet.Magnet. Mat, 200, 515-531.

Advances in Forest Fire Research 2018 - Page 512 
Quintiere J, Harkleroad M (1984), New Concepts for Measuring Flame Spread Properties, National Bureau of Standards, Gaithersburg, MD NBSIR 84-2943.

Rothermel RC (1972), A mathematical model for predicting fire spread in wildland fuels. USDA For. Serv. Res. Pap. INT-115. 40.

Stauffer D, Aharony A (Eds) (1992), 'Introduction to Percolation Theory', (Taylor and Francis, London).

Terrah SM, Zekri N (2018), Is there a critical fuel moisture content for flamability? (This conference)

Torero J (2016), Flaming ignition of solid fuels In 'SFPE Handbook of fire protection engineering' (Ed MJ Hurley) pp 633-661 (Springer: Heidelberg)

Trabaud L (1992), 'Les feux de forêt: mécanismes, comportement et environnement', (France selection, Paris)

Stanley HE (1971) 'Introduction to phase transitions and critical phenomena' (Clarendon Press Oxford)

Viegas DX, Raposo J, Davim D, Rossa C (2012), Analysis of the physical processes associated with junction fires at laboratory and field scales, Int. J.Wildland Fire, 21, 843-856

Weise DR, White RH, Beall FC, and Etlinger M (2005), Use of the cone calorimeter to detect seasonal differences in selected combustion characteristics of ornamental vegetation. Int. J.Wildland Fire, $14,321-338$.

Yeomans JM (1992) 'Statistical mechanics of phase transitions' (Clarendon Press Oxford)

Zekri N, Porterie B, Clerc J-P, Loraud J-C (2005) Propagation in a two-dimensional weighted local small-world network, Phys. Rev.E 71, 046121. 